\title{
DNA TeChNiQues APPLIED to the IDENTIFICATION OF PINCTADA FuCATA PeARlS From UWAJIMA, Ehime Prefecture, Japan
}

Kazuko Saruwatari, Michio Suzuki, Chunhui Zhou, Promlikit Kessrapong, and Nicholas Sturman

The genetic material deoxyribonucleic acid (DNA) is a useful indicator in identifying pearl species, provided the extraction and amplification of a targeted component is possible from amounts of pearl powder small enough to render the technique essentially nondestructive. This study builds on similar work carried out by Meyer et al. (2013) but focuses on akoya cultured pearls from Uwajima in Ehime Prefecture, Japan. Here, we also target the 16S rRNA genes, the mitochondrial component of DNA to code 16S rRNA (ribosomal ribonucleic acid). We successfully amplified the $16 \mathrm{~S}$ rRNA gene from the mantle tissues of donor and host pearl oysters and from 5$10 \mathrm{mg}$ of pearl powder samples. The results indicate a match with the Pinctada fucata 165 rRNA gene.

M odern pearl identification-including the type of pearl and any treatment applied-is performed by applying almost exclusively nondestructive methods. These include macro to microscopic observations, spectroscopy, chemical analysis, fluorescence, and various forms of X-ray imaging (Scarratt, 2011). Surface inspection differentiates nacreous from non-nacreous pearls, while chemical analyses using X-ray fluorescence and luminescence can distinguish between saltwater and freshwater pearls (e.g., Hänni, 2000; Hänni et al., 2005; Kessrapong et al., 2017). Internal inspection using X-radiography, which was introduced to gemology in the 1930s (Dirlam and Weldon, 2013), has evolved into high-tech X-ray computed microtomography $(\mu-C T)$. This technology enables more consistent separation of natural, non-bead-cultured, and bead-cultured pearls (e.g., Sturman, 2009; Karampelas et al., 2010).

One of the ongoing challenges is to identify the saltwater mollusk species producing white, cream, or silver nacreous pearls, since these can form in all Pinctada species as well as some other species, and

See end of article for About the Authors and Acknowledgments.

Gems \& Gemologr, Vol. 54, No. 1, pp. 40-50,

http://dx.doi.org/10.5741/GEMS.54.1.40

(C) 2018 Gemological Institute of America can have similar appearances. As pearls are formed by mollusks, a direct identification method would be to find biological evidence such as DNA indicators. (For boldfaced terms, please refer to the glossary on pp. 48-49.)

\section{In Brief}

- DNA technique was applied to identify saltwater mollusk species of akoya pearl from Uwajima, Ehime, Japan.

- $16 \mathrm{~S}$ rRNA genes, which are DNA components in mitochondria, were successfully extracted from the tissue of two mollusks and from 5-10 mg of powder from four pearl samples.

- All amplified nucleotide sequences of the 165 rRNA genes matched with those of Pinctada fucata.

DNA studies emerged in the biological sciences (e.g., Toro, 1998; Masaoka and Kobayashi, 2004; Freier et al., 2008) after the development during the 1980s of the polymerase chain reaction (PCR) method of duplicating gene fragments (see figure 1A). A number of studies on pearl oysters of the Pinctada species (e.g., Masaoka and Kobayashi, 2006; Tëmkin, 2010; Masaoka et al., 2016) have investigated their nuclear and mitochondrial ribosomal ribonucleic acid (rRNA) and the internal 


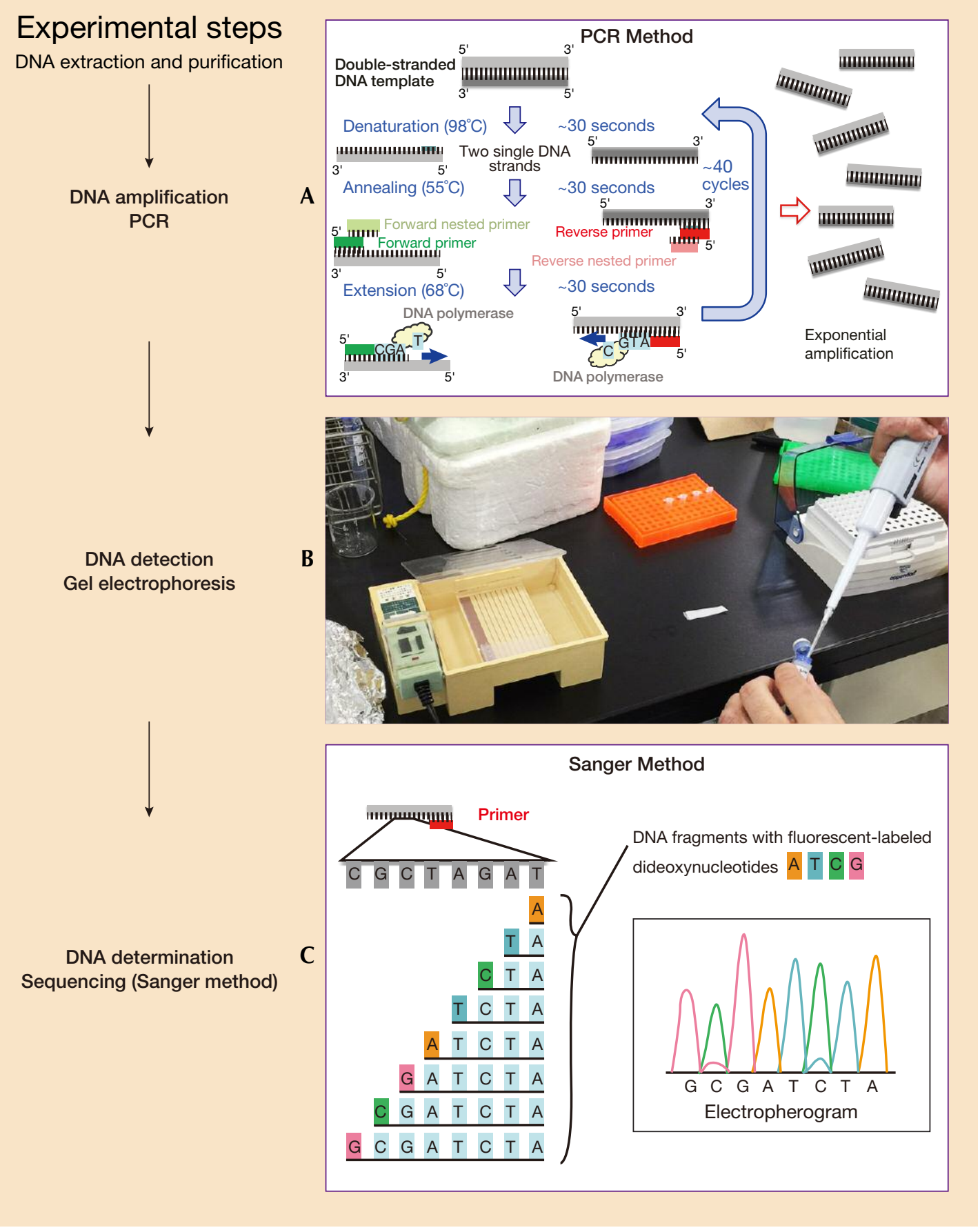

Figure 1. Experimental flow and their images. A: The polymerase chain reaction (PCR) process of denaturation, annealing, and extension. B: The gel electrophoresis step of the polymerase chain reaction (PCR) process is captured here. Four plastic $1.5 \mu \mathrm{L}$ PCR tubes, which possibly contain amplified target DNA samples, are aligned in the orange container in the middle. The yellow box on the left is a gel electrophoresis well set, with translucent agarose gel at the lower well wall. The researcher is trying to remove $1 \mu \mathrm{L}$ of loading dye to confirm the mobility of DNA during electrophoresis, and will mix it with $1 \mu \mathrm{L}$ of PCR product for a total of $2 \mu \mathrm{L}$ of mixture in the agarose gel for electrophoresis. Photo by K. Saruwatari. C: Schematic figure of the Sanger method. The figure on the left indicates DNA fragments with fluorescent-labeled dideoxynucleotides. The figure on the right is the electropherogram indicating DNA sequence after detecting the fluorescence-labeled dideoxynucleotides using capillary electrophoresis. 


\section{Box A: History of Pearl Culturing at Uwajima}

Uwajima, in Ehime Prefecture, is Japan's main pearl culturing area, followed by Mie and Nagasaki prefectures (figure A-1, A and B). The 2014 production was 7,724 kg for Ehime, 6,650 kg for Nagasaki, and 4,375 $\mathrm{kg}$ for Mie (Ministry of Agriculture, Forestry, and Fisheries, n.d.). The pearl farms in Uwajima are located along the coast-


Figure A-1. A: Map of Japan showing the three main prefectures for cultured pearl production: Ehime, Mie, and Nagasaki. B: EXpanded view of Ehime (in pink) showing the location of Uwajima and the Uwa-sea region (shaded in blue) along the southwestern coast. $C$ : View of the Uwajima coast, where the floating pearl rafts are visible. Photo by K. Saruwatari. D: A comparison of Ehime's pearl production from 1964 to 2014 with overall Japanese production during those years. Uwajima's pearl production from 1989 to 2014 is also shown. Sources: Ehime Prefectural Government Planning Promotion Division (n.d.) and Ministry of Agriculture, Forestry and Fisheries (n.d.). transcribed spacer (ITS) regions of nuclear rRNA genes while discussing the phylogeny and identification of the species.
According to these studies, pearl oysters can be classified into three groups-(1) P. maxima, (2) P. margaritifera, and (3) akoya-type-that have differ- 
line (figure A-1, C), continuing to the south of Ainan. The coastline between the two cities, referred to as Uwa-sea, is known to produce wild akoya oysters. The city has ranked first in Japanese production of akoya bead-cultured pearls in both volume and value for several recent years, according to municipal statistics (figure A-1, D; see also Ministry of Agriculture, Forestry, and Fisheries, n.d.). Most culturing pearl farms in the waters off Uwajima and the surrounding area were established around 1948 (Ehime Prefectural Lifelong Learning Center, 1984 a,b), though the oldest oyster harvesting business listed in Ainan historical records began in 1907.

Since 1957, the prefecture government's policy has been to separate akoya oyster hatcheries and pearl culturing businesses, while permitting only local fisheries to rear mollusks. In 1967, Ehime ranked second in Japanese pearl production (after Mie Prefecture, where Kokichi Mikimoto first cultured pearls). But due to a recession that began that same year, cultured pearl export prices went into a decline that continued until 1971. To overcome the challenging economic situation, pearl-related parties such as farmers and traders attempted to impose controls, remove lowquality pearls from production, reduce storage of overproduced pearls, and apply other measures, but this did not prevent many small businesses across Japan from going bankrupt. However, small businesses in the region around Uwajima were able to survive because the production of medium-size $(7 \mathrm{~mm})$ pearls was less severely affected. This was due to several factors, including the relatively short culturing periods; local sourcing of better-quality, less-expensive host akoya oysters; and the area's favorable fishery conditions. By 1972, the Japanese pearl industry had recovered and stabilized.

Ehime Prefecture ranked first nationwide in pearl production and income from 1974 until 1996, when a virus decimated the akoya oysters (Morizane et al., 2001). The Uwa-sea region was unable to escape the effect of the outbreak, resulting in a drastic decrease in akoya production to a mere $20 \%$ of the previous high. Since steps were taken to hybridize Japanese with Chinese/Vietnamese akoya oysters that would be resistant to infection, production has recovered (Morizane, 2012) and Ehime has been the top-producing prefecture since 2009 (Ehime Prefectural Government Planning Promotion Division, n.d.).

ent nuclear 28S rRNA and mitochondrial 16S rRNA genes. Akoya-type oysters include P. fucata (Indo-Pacific region), P. radiata (eastern Indian Ocean to Red
Sea), and P. imbricata (western Atlantic region), that have the same nuclear 28S rRNA gene but different mitochondrial 16S rRNA genes (Masaoka et al., 2016). Thus, DNA investigation has demonstrated that the members of the akoya pearl oyster group are genetically very closely related species but distinct genealogical units, suggesting subspecies-level differences (Tëmkin, 2010). Tëmkin also pointed out that it might be meaningful to treat the three individual akoya populations as evolutionary significant units, because they originated from three different geographic regions. 16S rRNA genes differ in all five of the most abundant pearl oysters (P. maxima, $P$. margaritifera, $P$. fucata, $P$. imbricata, and P. radiata), making them very useful DNA markers to identify the Pinctada species or subspecies.

The targeted component of the DNA, the 16S rRNA gene, is the component necessary to code the 16S rRNA, essential in the process of biological protein synthesis. Because the cells of higher-order animals are known to have many copies, the DNA regions have the advantage of developing sensitive PCR-based identification methods (Masaoka and Kobayashi, 2005). Furthermore, 16S rRNA genes are conserved within a Pinctada species but contain sufficient variation between species to produce speciesspecific sequences (Masaoka and Kobayashi, 2004, 2005). These sequences have been registered in GenBank, the genetic sequence database of the National Institutes of Health's National Center for Biotechnology Information (NCBI).

Using a micro-drilling method, Meyer et al. (2013) succeeded in extracting nuclear and mitochondrial DNA samples and identifying the pearl oyster species as $P$. margaritifera, $P$. maxima, or P. radiata. For the present study, akoya cultured pearl oysters were sampled during harvesting (hamaage) in Uwajima, in Japan's Ehime Prefecture, with the purpose of extracting DNA and the mitochondrial 16S rRNA gene from minute amounts of pearl powder and tissues of $P$. fucata. (For the history of pearl culturing in Uwajima, see box A.) Our goal was to conclusively identify the species and use that as a reference for determining the whole targeted DNA sequence. The Japanese akoya pearl oysters $P$. martensii and $P$. fucata martensii have been distinguished from $P$. fucata based on the classical biological classification such as shell morphologies in most cases (e.g., Hayami, 2000; Masaoka and Kobayashi, 2004). However, their genetic properties are very similar, with the same 16S rRNA genes, indicating that $P$. fucata and $P$. martensii are genetically much closer to other 
TABLE 1. List of DNA samples and results.

\begin{tabular}{|c|c|c|c|c|c|c|}
\hline & Sample & PCR using Ex-Taq & $\begin{array}{c}\text { Nested PCR } \\
\text { using Ex-Taq }\end{array}$ & PCR using $\mathrm{KOD}^{\mathrm{b}}$ & PCR data in figure 3 & $\begin{array}{c}\text { Sequence result } \\
\text { (P. fucata matching) }\end{array}$ \\
\hline Donor oyster 4 & Mantle tissue & $\circ$ & - & - & (a) & 524 bp $(100 \%)$ \\
\hline Host oyster 14 & Mantle tissue & $\circ$ & - & - & (b) & 524 bp (100\%) \\
\hline Pearl 12 cream & $9.33 \mathrm{mg}(0.046 \mathrm{ct})$ & $x$ & $x$ & $\circ$ & (d) & 524 bp $(100 \%)$ \\
\hline Pearl 14 cream & $7.37 \mathrm{mg}(0.037 \mathrm{ct})$ & $x$ & $\circ$ & $x$ & (c) & 524 bp (100\%) \\
\hline Pearl 19 cream & $6.03 \mathrm{mg}(0.030 \mathrm{ct})$ & $x$ & $x$ & $\circ$ & (e) & 524 bp (100\%) \\
\hline Pearl 20 cream $^{\mathrm{a}}$ & $5.27 \mathrm{mg}(0.026 \mathrm{ct})$ & $x$ & $x$ & ० & $(f)$ & 350 bp (100\%) \\
\hline \multicolumn{7}{|c|}{$\begin{array}{l}{ }^{a} \text { Only forward sequence data was obtained for pearl no. 20, resulting in a matching sequence molecular weight of } 350 \mathrm{bp} \text { in total } 820 \mathrm{bp} \text { (see supplementary figure } S \text {-1 } \\
\text { at https://www.gia.edu/gems-gemology/spring-2018-DNA-identification-pinctada-fucata-pearls-data-supplement). } 0 \text { and X indicate PCR success and failure respectively. } \\
\text { bAn enzyme } \\
{ }^{c} \text { bp = base pairs }\end{array}$} \\
\hline
\end{tabular}

akoya-type species such as $P$. radiata and $P$. imbricata (Masaoka and Kobayashi, 2004; Wada and Tëmkin, 2008). This study treats $P$. martensii as a subspecies of $P$. fucata, as their $16 \mathrm{~S}$ rRNA genes have the same DNA sequence alignments.

\section{MATERIALS AND METHODS}

The shells sampled for this project were collected from live pearl oysters in January 2016 at Uwajima (see the harvesting details in figure 2). Thirty-seven pearl oysters, consisting of 28 host oysters used to grow pearls and nine donor oysters bred for tissue grafting, were collected after they were confirmed to be alive and immediately transported to the University of Tokyo. The shells were dissected, and both the mantle and pearl samples were frozen and stored at $-80^{\circ} \mathrm{C}$ until analysis was possible. For DNA extraction experiments, the mantle tissue of a host oyster and a donor oyster were selected together with four pearls (see table 1).

Our strategy was to use a simple direct sequence method consisting of three experimental steps: (1) DNA extraction and subsequent purification, (2) amplification and detection, and (3) sequencing. For the first steps of DNA extraction and purification, 16S rRNA gene extraction from mantle tissues was performed using a general phenol-chloroform extraction process (see Suzuki et al., 2004), whereas 16S rRNA genes were obtained from pearl powder samples using a method similar to that described in Meyer et al. (2013). The second step of DNA amplification consists of the PCR and nested PCR methods (figure 1A). The PCR method consists of three repeating processes: denaturation, annealing, and extension using the PCR machine. Denaturation is separating the targeted DNA double strands, called "DNA tem- plates," into two single strands. Annealing is a connecting process of the single DNA strands with forward or reverse primers, which are artificially aligned short nucleotides (about 10-15 nucleotides). Extension is extending the double chain of the single DNA strands with available nucleotides, called deoxynucleotides (see figure 1B). These three processes are repeated for 30-40 cycles, and targeted DNA (the 16S rRNA gene) should be amplified exponentially. The nested PCR method is known to improve PCR sensitivity for specific DNA amplification and is often used for complementary DNA cloning (e.g., Suzuki et al., 2004; Liu et al., 2007), as well as to recover ancient DNA (e.g., Salo et al., 1994; Yang et al., 1997). Meyer et al. (2013) also applied the nested PCR method after drilling pearl samples to obtain as little as $10 \mathrm{mg}$ of powder and succeeded in amplifying nuclear ITS2 regions (refer to glossary for the definition of ITS). The determination of whether DNA was amplified was performed using a gel electrophoresis method (figure 1B). Negatively charged DNA molecules migrate though the gel when an electric field is applied and are separated based on their size. Thus this method produces the quantity and approximate molecule size of amplified DNA necessary for the third step of sequencing. We applied the Sanger method to determine the nucleotide arrangement (figure 1C), added fluorescent-labeled dideoxynucleotides to amplify the DNA template, and subsequently generated DNA fragments as the dideoxynucleotides terminated the DNA extension process (figure 1C, left). The DNA fragments were separated by capillary electrophoresis on the basis of the size, producing the electropherogram as the final sequence result (figure $1 \mathrm{C}$, right). The detailed DNA extraction to detection methods are described in box B. 

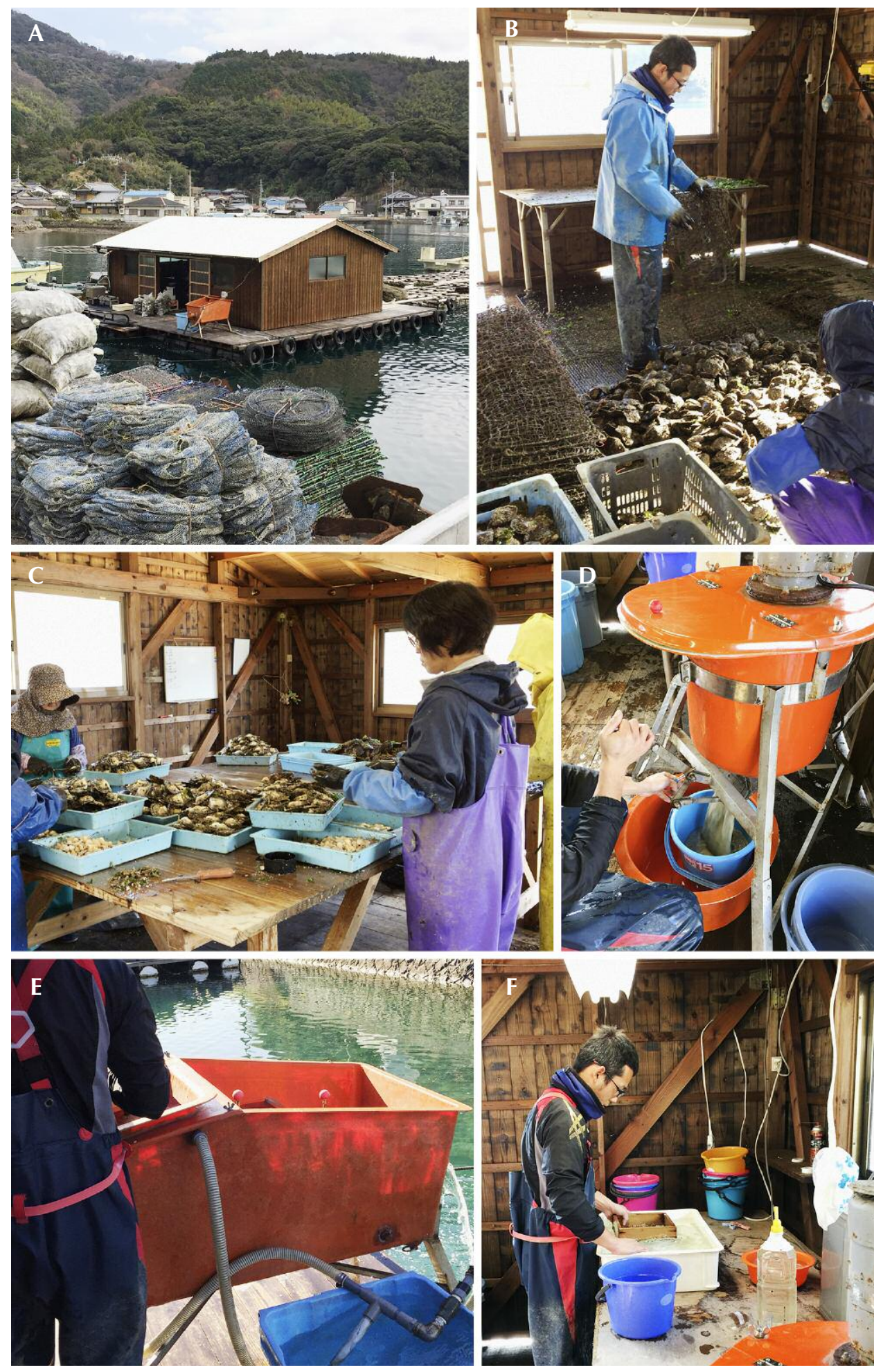

Figure 2. Between November and January of each year, pearls are harvested at Uwajima from akoya shells operated on either six months prior (classified by the Japanese as tonen-mono) or 18 months prior (koshimono). A: An Uwajima pearl farmer's work hut. $B-F$ : Various scenes from harvesting in a shed on one of the floating rafts. $B$ : Oysters are removed from a net on the floor to separate the living mollusks from the dead ones. C: After the shells are opened on a table, the adductor muscles are removed and the other soft tissues are separated. D: The liquefied soft tissues containing the bead-cultured pearls are collected in a blue plastic bucket. E: The remaining organic matter containing smaller "keshi" pearls is poured into a separator to remove the keshi pearls. F: The bead-cultured pearls are placed into a wooden box for cleaning and subsequent inspection. Photos by K. Saruwatari.

\section{RESULTS AND DISCUSSION}

Figure 3 shows the PCR and nested PCR products of the 16S rRNA gene obtained from the gel electrophoresis process. All the bands appeared at ap- proximately 500 base pairs (bp) of molecular weight markers, and the resulting forward and reverse sequences mostly matched with 524 bp of P. fucata (see table 1 and supplementary figure $S-1$ at 


\section{Box B: Pearl DNA Extraction to Detection—Experimental Detalls}

To prepare the samples for testing, we cleaned the pearls in $4 \%$ sodium hypochlorite solution for 20 minutes with no obvious change of appearance, and then peeled the nacreous layers using a drill to obtain minute samples of pearl powder $(5.27-9.33 \mathrm{mg}$, or $0.026-0.047 \mathrm{ct}$; see table 1 and figure B-1). The pearls were severely damaged since they were only in the mollusks for around six months (tonen-mono) and possessed very thin nacreous overgrowths. The effect of the bead nucleus is considered insignificant because the nuclei are mostly produced from Mississippi River mussels-i.e., Fusconia flava, Potamilis alatus, and Quadrula quadrula-belonging to the Unionidae family (Dirlam and Weldon, 2013).

The 16S rRNA genes of the three Mississippi River mussels mentioned above are registered in GenBank; their homologies (shared ancestries) with the 16S rRNA gene of $P$. fucata are only $52-53 \%$. This indicates that the PCR primers for Pinctada species will not amplify the 16S rRNA genes present within bead nuclei.

The powder samples from each pearl were dissolved in 500 microliters $(\mu \mathrm{L})$ of $0.5 \mathrm{M}$ EDTA $(\mathrm{pH} 8)$ and vigorously vortexed for two minutes and subsequently incubated overnight at $56^{\circ} \mathrm{C}$ in a water bath in accordance with the procedures of Meyer et al. (2013). For DNA extraction we used the commercial FastDNA SPIN Kit for Soil (MP Biomedicals) in accordance with the manufacturer's recommendations, with two exceptions:

1) Rather than using the Lysing Matrix E tubes provided in the kit, the $978 \mu \mathrm{L}$ sodium phosphate buffer was added directly to the microfuge tube of pearl-EDTA solution.

2) Instead of performing the fourth step of homogenization with the FastPrep instrument, the samples were vortexed vigorously for two minutes.

The extracted DNA samples underwent PCR amplification using a Takara TP600 PCR Thermal Cy- cler Dice Gradient). PCR was carried out with a mixture of $0.25-0.50 \mu \mathrm{L}$ of DNA template, $0.05 \mu \mathrm{L}$ Takara Bio's Ex-Taq PCR enzyme, $1 \mu \mathrm{L}$ of PCR enzyme buffer, $1 \mu \mathrm{L}$ of dNTP mixture $(2.5 \mathrm{mM}), 0.5 \mu \mathrm{L}$ of each forward and reverse primer $(10 \mathrm{mM}$; forward 5'-CGCCTGGTTGATTAAAAACATTGCTGC-3' and reverse: 5'-CCGGTTTGAACTCAGATCACGTA-3') according to Meyer et al. (2013), and $7 \mu \mathrm{L}$ of Milli-Q water. The total amount was $10.30-10.55 \mu \mathrm{L}$ for the PCR process. The PCR cycle involved a prereaction step at $96^{\circ} \mathrm{C}$ for three minutes, followed by 35 cycles of denaturation at $96^{\circ} \mathrm{C}$ for 30 seconds, annealing at $55^{\circ} \mathrm{C}$ for 30 seconds, and elongation at $72^{\circ} \mathrm{C}$ for 30 seconds. Nested PCR followed the same procedure as the first PCR process but used inner primers (forward: 5'-AAAAACATTGCTGCACGGA-3' and reverse: 5'-ACTCAGATCACGTAGGGCTT-3').

Initial attempts at amplifying DNA from three pearl samples using the Ex-Taq enzyme did not succeed; another attempt, using a different PCR enzyme, KOD FX Neo (Toyobo Co., Ltd.), was successful (see table 1). PCR using KOD FX Neo enzyme was carried out with a mixture of $0.5 \mu \mathrm{L}$ of DNA template, $0.5 \mu \mathrm{L}$ of PCR enzyme, KOD FX Neo, $12.5 \mu \mathrm{L}$ of PCR enzyme buffer, $5 \mu \mathrm{L}$ of dNTP mixture $(2 \mathrm{mM}), 0.5 \mu \mathrm{L}$ of each forward and reverse primer, and $5.5 \mu \mathrm{L}$ of Milli-Q water. The total amount was $25 \mu \mathrm{L}$ for the PCR process. After detecting the amplified DNA using the gel electrophoresis method, the amplified DNA samples were concentrated by ethanol precipitation and diluted using 10 $\mu \mathrm{L}$ distilled water. The samples were then divided into two $5 \mu \mathrm{L}$ batches. The forward and reverse sequencing were prepared by adding $0.5 \mu \mathrm{L}$ of primer $(10 \mathrm{mM})$ to each batch and diluting that into $13 \mu \mathrm{L}$ for the next sequencing process. While all the samples were prepared by authors KS and MS, the 16S rRNA sequencing was outsourced to the Japan Food Analysis and Biotechnology Company (FASMAC), where the Sanger sequencing method was applied.
www.gia.edu/gems-gemology/spring-2018-DNAidentification-pinctada-fucata-pearls-data-supplement). For one pearl sample (no. 20) we only obtained the forward sequence with $820 \mathrm{bp}$ in total. However, the part of the sequence with $350 \mathrm{bp}$ is perfectly matched within the part of the 524 bp range expected for $P$. fucata and not with sequences of the other Pinctada species on record, including $P$. radiata and $P$. imbricata (see supplementary figure S-2 at https://www.gia.edu/gems-gemology/spring- 

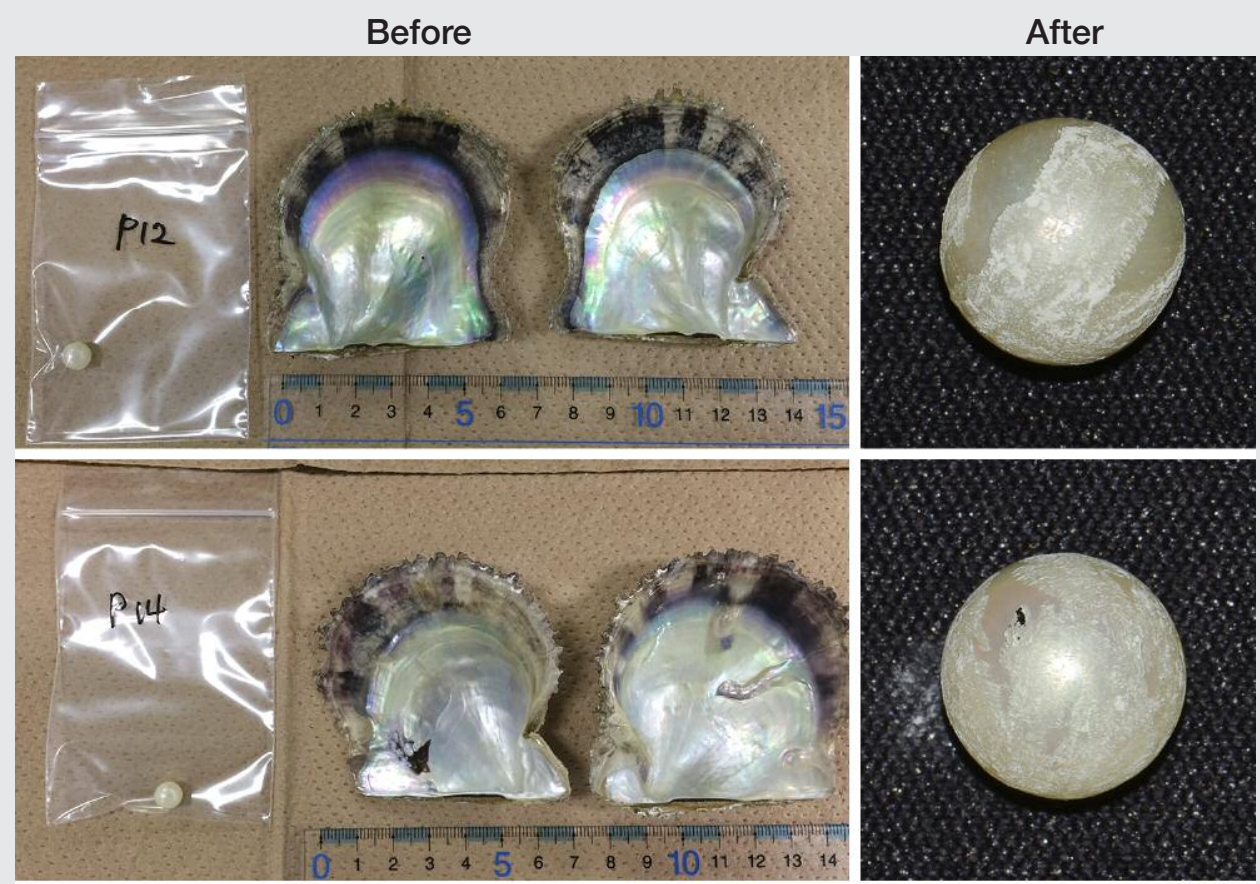

Figure B-1. The akoya pearl samples used in this study. The photos on the left show the specimens in plastic bags (along with the host oysters) before the powder samples were
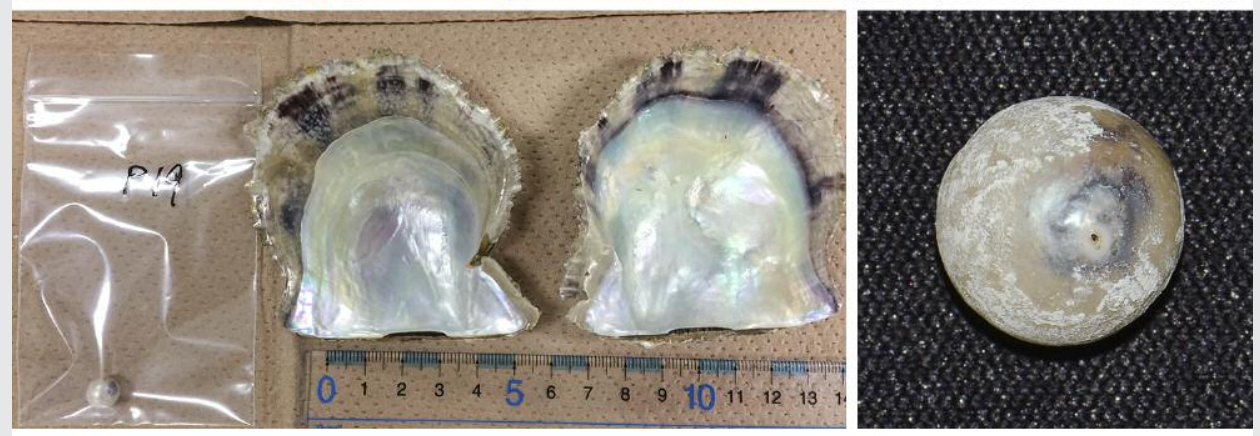
obtained. Photos by K. Saruwatari. The photos on the right, taken after the powder samples were obtained, show severely damaged pearls and exposed inner nuclei. Photos by $S$. Nagai.
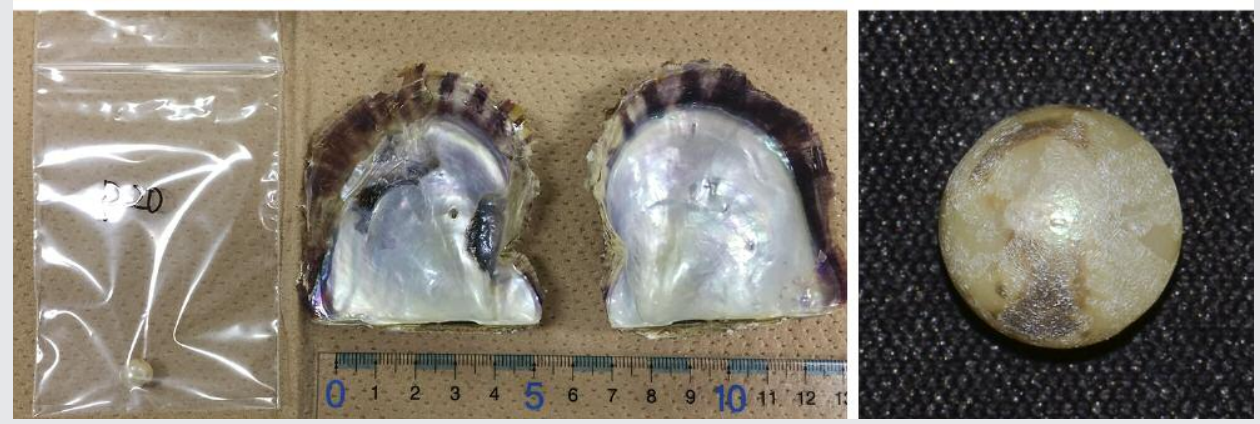

2018-DNA-identification-pinctada-fucata-pearlsdata-supplement). Thus, all the 16S rRNA gene samples obtained matched $P$. fucata.

In this study, it was possible to extract DNA from 5 to $10 \mathrm{mg}$ of pearl powder, but the pearls were se- verely damaged in the process (see figure B-1, right column). To apply the DNA methods effectively within the pearl industry, further improvements to the extraction step are clearly needed. Reducing the sample size required to approximately $0.01 \mathrm{mg}$ 


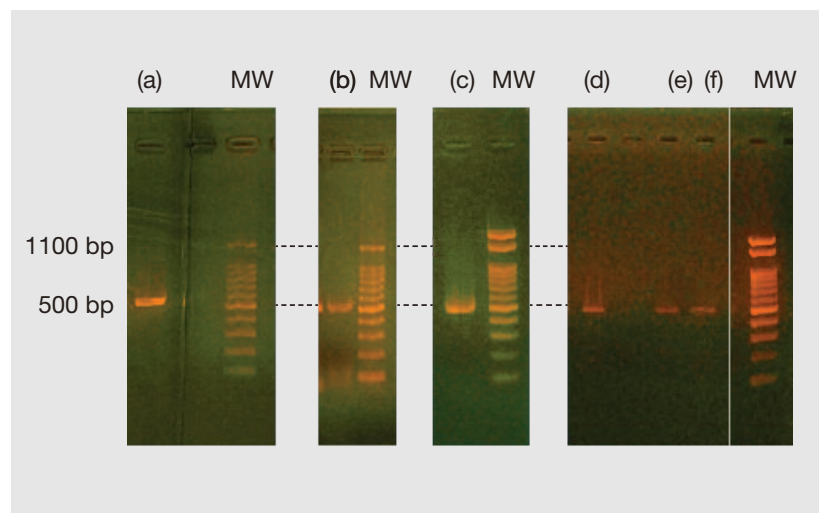

Figure 3. Experimental results of the gel electrophoresis process; letters (a)-(f) correspond with those in table 1. MW (molecular weight) markers for (a) and (d) were obtained from two separate gels during each electrophoresis experiment. The sequence data results are given in table 1. Photo by K. Saruwatari

would be one such improvement. This would equate to the approximate amount ablated during laser ablation-inductively coupled plasma-mass spectroscopy (LA-ICP-MS) chemical measurements (Hänni and Cartier, 2013). DNA amplification using PCR was improved by (1) the application of the nested PCR method and (2) the use of two different types of PCR polymerase: Taq-type and KOD-type (summarized in table 1).

A powder sample was obtained from pearl sample no. 14 to successfully amplify the $16 \mathrm{~S}$ rRNA using the nested PCR method with a Taq-type polymerase similar to that applied by Meyer et al. (2013). The DNA of the other three pearl samples was amplified using only the first (non-nested) PCR with a KOD- type polymerase. The advantage of KOD-type polymerase is that it has $3^{\prime} \rightarrow 5^{\prime}$ exonuclease activity (Morikawa et al., 1994), which is an active process mechanism of "proofreading" the polymerase chain reaction. The Taq polymerase does not have this proofreading activity. At present it is not known why different polymerase activities for the pearl samples occurred, but they may help amplify 16S rRNA genes in various pearl powder samples.

Future research needs to address the effects of any treatments, such as maeshori or bleaching, on DNA extraction. Although the species and distinction of the akoya-type pearl oysters are still under discussion, the draft genome of $P$. fucata has been provided by Takeuchi et al. (2012) and ongoing DNA studies will continue. Future results will aid in species identification and may also provide evidence of the geographic region where pearls formed, benefiting the pearl industry in matters of traceability.

\section{CONCLUSIONS}

The 16S rRNA genes extracted from the mantle tissues of one donor shell and one host shell fully matched the complete sequence of $P$. fucata. The $16 \mathrm{~S}$ rRNA genes extracted from the powder of the nacreous layers of four bead-cultured pearl samples were also found to match the sequence of $P$. fucata. Thus, the pearl oysters and pearl samples obtained in January 2016 from Uwajima were categorically identified as originating from $P$. fucata species. From a methodology perspective, it was possible to identify the $P$. fucata $16 \mathrm{~S}$ rRNA gene from only 5 to $10 \mathrm{mg}$ of pearl powder sample weight, compared to the 10 to $100 \mathrm{mg}$ quantity previously reported by Meyer et al. (2013). This reduced sampling is important when analyzing pearls of historical significance and value.

\section{GlOSSARY}

Base pair (bp): A pairing of the molecules that comprise DNA, specifically an adenine $(\mathrm{A}) /$ thymine $(\mathrm{T})$ or guanine (G)/cytosine (C) pair.

Deoxyribonucleic acid (DNA): The hereditary material in humans and almost all other organisms. Most DNA is located in the cell nucleus, but a small amount can also be found in the mitochondria. Complementary DNA is DNA synthesized by reverse transcription reaction of messenger RNA.

Dideoxynucleotide: A type of nucleotide that terminates the DNA extension process, as it does not contain the $\mathrm{OH}^{-}$ (hydroxyl) groups needed for extending DNA chains. 
Electropherogram: Diagram produced by electrophoresis.

Exonuclease activity: An activity of an enzyme to hydrolyze a DNA chain sequentially from the end of a polynucleotide molecule.

Evolutionary significant unit: A population of subspecies organisms that is considered distinct for conservation purposes. Proposed by Ryder (1986).

Gene: The basic physical and functional unit of heredity. A "gene" is encoded by DNA and usually acts as a template to make a protein.

Internal transcribed spacer (ITS): The gene regions between nuclear rRNA genes.

Koshi-mono: The Japanese term for akoya cultured pearls removed from mollusks 12 months or more after seeding.

Mitochondrion: An organelle in cells that have a nu- cleus, as in plants and animals.

Organelle: Small, specialized structures in cells that operate like organs by carrying out specific tasks.

Polymeric: Referring to an aggregate of monomers or combined molecules.

Protein: A molecule consisting of amino acids that carries out functions related to an organism's biology.

Phylogeny: The history of the evolution of a species.

Ribonucleic acid (RNA): A polymeric molecule involved in various biological roles for coding, decoding, regulation, and expression of genes. 16S rRNA (16S ribosomal RNA) is a component of ribosomal RNA, and its gene is coded in mitochondria.

Tonen-mono: The Japanese term for akoya cultured pearls removed from the mollusks within a year of seeding.

\section{ABOUT THE AUTHORS}

Dr. Saruwatari is supervisor of colored stone identification at GIA in Tokyo. Dr. Suzuki is an associate professor in the department of applied biological chemistry at the University of Tokyo. Dr. Zhou is a research scientist and manager of pearl identification at GIA in New York. Mr. Kessrapong is a staff gemologist, and Mr. Sturman is senior manager of identification, at GIA in Bangkok.

\section{ACKNOWLEDGMENTS}

The authors appreciate the assistance of Dr. Ahmadjan Abduriyim (Tokyo Gem Science and GSTV Gemological Laboratory) and Matsumoto Pearl Co., Ltd. (Uwajima, Ehime, Japan), on various aspects of this project. Dr. Hirotoshi Endo (Tsukuba University), the three peer reviewers, and Mrs. Artitaya Homkrajae (GIA, Carlsbad) are also thanked for their discussions and constructive suggestions to improve the article.

\section{REFERENCES}

Dirlam D.M., Weldon R. (2013) Splendour and Science of Pearls. Gemological Institute of America, Carlsbad, CA, 139 pp.

Ehime Prefectural Government Planning Promotion Division (n.d.) Ehime fisheries statistics, http://www.pref.ehime.jp/ h37100/toukei/ [in Japanese].

Ehime Prefectural Lifelong Learning Center (1984a) Ehime prefecture history journal II: Seven Uwaumi pearl culture (1985) http://www.i-manabi.jp/system/regionals/regionals/ecode:2/ 34/view/4928 [in Japanese].

(1984b) Ehime prefecture history journal I (General): Fishery cultivation. http://www.i-manabi.jp/system/regionals/regionals/ ecode:2/31/view/4389 [in Japanese].
Freier R., Fernández-Tajes J., Méndez J. (2008) Identification of razor clams Ensis arcuatus and Ensis siliqua by PCR-RFLP analyses of ITS1 region. Fisheries Science, Vol. 74, No. 3, pp. 511-515, http://dx.doi.org/10.1111/j.1444-2906.2008.01553.x

Hänni H.A (2000) Freshwater cultured "Kasumiga pearls" with akoya cultured pearl nuclei. GÆ G, Vol. 36, No. 2, pp. 167-168.

Hänni H.A., Cartier L.E. (2013) Tracing cultured pearls from farm to consumer: A review of potential methods and solutions. Journal of Gemmology, Vol. 33, No. 7-8, pp. 239-245.

Hänni H.A., Kiefert L., Giese P. (2005) X-ray luminescence, a valuable test in pearl identification. Journal of Gemmology, Vol. 29 , No. 5/6, pp. 325-329. 
Hayami I. (2000) Family Pteriidae order Pterioida. In T. Okutani, Ed., Marine Mollusks in Japan. Tokai University Press, Tokyo, pp. 879-883 [In Japanese with English species and descriptions].

Karampelas S., Miche J., Zheng-Cui M., Schwarz J-O., Enzmann F., Fritsch E., Leu L., Krzemnicki M.S. (2010) X-ray computed microtomography applied to pearls: Methodology, advantages, and limitations. $G \uplus G$, Vol. 46, No. 2, pp. 122-127, http://dx.doi.org/10.5741/GEMS.46.2.122

Kessrapong P., Lawanwong K., Sturman N. (2017) Pinctada maculata (Pipi) bead-cultured blister pearls attached to their shells, Apr. 25, https://www.gia.edu/gia-news-research/pinctadamaculata-bead-cultured-blister-pearls-shells

Liu H.-L., Liu S.-F., Ge Y.-J., Liu J., Wang X.-Y., Xie L.-P., Zhang R.Q., Wang Z. (2007) Identification and characterization of a biomineralization related gene PFMG1 highly expressed in the mantle of Pinctada fucata. Biochemistry, Vol. 46, pp. 844-851, http://dx.doi.org/10.1021/bi061881a

Masaoka T., Kobayashi T. (2004) Polymerase chain reaction-based species identification of pearl oyster using nuclear ribosomal DNA internal transcribed spacer regions. Fish Genetics and Breeding Science, Vol. 33, pp. 101-105.

- (2005) Species identification of Pinctada imbricata using intergenic spacer of nuclear ribosomal RNA genes and mitochondrial 16S ribosomal RNA gene regions. Fisheries Science, Vol. 71, pp. 837-846, http://dx.doi.org/10.1111/j.14442906.2005.01035.x

(2006) Species identification of Pinctada radiata using intergenic spacer of nuclear ribosomal RNA genes and mitochondrial 16S ribosomal RNA gene regions. Fish Genetics and Breeding Science, Vol. 35, pp. 49-59.

Masaoka T., Okamoto H., Araki K., Nagoya H., Fuijwara A., Kobayashi T. (2016) Distinction between Pinctada species based on nuclear and mitochondrial ribosomal RNA gene regions. DNA Testing, Vol. 8, pp. 9-21.

Meyer J.B., Cartier L.E., Pinto-Figueroa E.A., Krzemnicki M.S., Hänni H.A., McDonald B.A. (2013) DNA fingerprinting of pearls to determine their origins. PLOS One, Vol. 8, No. 10, pp. 1-11, http://dx.doi.org/10.1371/journal.pone.0075606

Ministry of Agriculture, Forestry, and Fisheries (n.d.) Sea surface fishery production statistics survey, http://www.maff.go.jp/j/ tokei/kouhyou/kaimen_gyosei/index.html [in Japanese].

Morikawa M., Izawa Y., Rashid N., Hoaki T., Imanaka T. (1994) Purification and characterization of a thermostable thiol protease from a newly isolated hyperthermophilic Pyrococcus sp. Applied and Environmental Microbiology, Vol. 60, No. 12, pp. 4559-4566.

Morizane T. (2012) Circumstances and current condition of pearl culturing at Ehime prefecture. JFSTA News, No. 17, pp. 1-10 [in Japanese].

Morizane T., Takimoto S., Nishikawa S., Matsuyama N., Tyohno K., Uemura S., Fuiita Y., Yamashita H., Kawakami H., Koizumi Y., Uchimura Y., Ichikawa M. (2001) Mass mortalities of Japanese pearl oyster in Uwa Sea, Ehime in 1997-1999. Japanese Society of Fish Pathology, Vol. 36, No. 4, 207-216, http://dx.doi.org/10.3147/jsfp.36.207 [in Japanese].

Ryder O.A. (1986) Species conservation and systematics: the dilemma of subspecies. Trends in Ecology e) Evolution, Vol. 1, pp. 9-10, http://dx.doi.org/10.1016/0169-5347/86)90059-5

Salo W.L., Aufderheide A.C., Buikstra J., Holcomb T.A. (1994) Identification of Mycobacterium tuberculosis DNA in a preColumbian Peruvian mummy. Proceedings of the National Academy of Sciences, Vol. 91, No. 6, pp. 2091-2094, http://dx.doi.org/10.1073/pnas.91.6.2091

Scarratt K. (2011) Pearl identification-A practitioner's perspective. Ge G, Vol. 47, No. 2, pp. 117-119.

Sturman N. (2009) The microradiographic structures of non-bead cultured pearls. GIA Thailand Lab Notes, http://www.giathai. net/pdf/The_Microradiographic_structures_in_NBCP.pdf

Suzuki M. Murayama E., Inoue H., Ozaki N., Tohse H., Kogure T., Nagasawa H. (2004) Characterization of Prismalin-14, a novel matrix protein from the prismatic layer of the Japanese pearl oyster (Pinctada fucata). Biochemical Journal, Vol. 382, pp. 205-213, http://dx.doi.org/10.1042/BJ20040319

Takeuchi T., Kawashima T., Koyanagi R., Gyoja F., Tanaka M., Ikuta T., Shoguchi E., Fujiwara M., Shinzaro C., Hisata K., Fujie M., Usami T., Nagai K., Maeyama K., Okamoto K., Aoki H., Ishiwaka T., Masaoka T., Fuijwara A., Endo K., Endo H., Nagasawa H., Kinoshita S., Asakawa S., Watabe S., Satoh N. (2012) Draft genome of the pearl oyster Pinctada fucata: A platform for understanding bivalve biology. DNA Research, Vol. 19, No 2, pp. 117-130, http://dx.doi.org/10.1093/dnares/dss005

Tëmkin I. (2010) Molecular phylogeny of pearl oysters and their relatives (Mollusca, Bivalvia, Pterioidea). BMC Evolutionary Biology, Vol. 10, p. 342, http://dx.doi.org/10.1186/1471-2148$10-342$

Toro J.E. (1998) Molecular identification of four species of mussels from southern Chile by PCR-based nuclear markers: The potential use in studies involving planktonic surveys. Journal of Shellfish Research, Vol. 17, No. 4, pp. 1203-1205.

Wada K.T., Tëmkin I. (2008) Taxonomy and phylogeny. In P.C. Southgate and J.S. Lucas, Eds., The Pearl Oyster, Elsevier, Oxford, UK, pp. 37-75.

Yang H., Golenberg E.M., Shoshani J. (1997) Proboscidean DNA from museum and fossil specimens: An assessment of ancient DNA extraction and amplification techniques. Biochemical Genetics, Vol. 35, pp. 165-179. 